\title{
PENGARUH KECUKUPAN MODAL (CAR), EFISIENSI OPERASIONAL (BOPO), DAN KUALITAS PEMBIAYAAN (NPF) TERHADAP PROFITABILITAS (ROA) PADA BANK SYARIAH DI INDONESIA
}

\author{
Suhadi* \\ E-mail: salwalubna44@gmail.com \\ Dewi Inaroh*
}

Abstract This study aims to determine the effect of Capital Adequacy Ratio (CAR), Operational Efficiency (BOPO), and Financing Quality (NPF), to Profitability (ROA) at Bank Syariah period 2009-2013. The sample in this research is quarterly financial report of 3 Bank Syariah (BRI Syariah, Bank Mandiri Syariah, and Bank Mega Syariah) period 2009-2013. Data analysis used classical assumption test. The result of the research shows that Operational Efficiency (BOPO) has significant effect to Profitability (ROA) with significance level of 0. $000 \%$ and tcount of 6, 900. While Capital Adequacy (CAR) and Financing Quality (NPF) did not affect the level of profitability (ROA) with the level of significance of each of $0.322 \%$ and $0.666 \%$ and t arithmetic respectively of 1,000 and 0. 435. While F test get F count equal to 20, 053 with significance level equal to $0.000 \%$, this indicates that Capital Adequacy Level (CAR), Operational Efficiency (BOPO), and Financing Quality (NPF), influence to Profitability (ROA). Combined independent variables of this study can explain the variability level of profitability (ROA) of Islamic banks by $49.2 \%$.

Keywords: capital, efficiency, profitability

\section{A. PENDAHULUAN}

Undang-Undang tersebut tertulis bahwa perbankan syariah bertujuan menunjang pelaksanaan pembangunan nasional dalam rangka meningkatkan keadilan, kebersamaan, dan pemerataan kesejahteraan rakyat. Bank adalah badan usaha yang menghimpun dana dari masyarakat dalam bentuk simpanan dan menyalurkannya kepada masyarakat dalam bentuk kredit dan atau bentukbentuk lainnya dalam rangka meningkatkan taraf hidup rakyat banyak. Dengan kata lain, bank dalam menjalankan aktivitasnya berfungsi sebagai lembaga intermediasi (financial intermediary), yaitu lembaga keuangan yang berfungsi sebagai perantara pihak yang kelebihan dana dengan pihak yang kekurangan dana. Fungsi bank sebagai lembaga intermediasi ini membuat

${ }^{*}$ STAIN Kudus 
bank memiliki posisi yang strategis dalam perekonomian, pasalnya, dengan aktivitasnya, yaitu menghimpun dana dan menyalurkan dana kepada masyarakat yang membutuhkan akan meningkatkan arus dana untuk investasi, modal kerja maupun konsumsi. Sehingga akan dapat meningkatkan perekonomian nasional. Undang-Undang tersebut tertulis bahwa perbankan syariah bertujuan menunjang pelaksanaan pembangunan nasional dalam rangka meningkatkan keadilan, kebersamaan, dan pemerataan kesejahteraan rakyat (Rachmadi Usman, 2009: 391).

Bank adalah badan usaha yang menghimpun dana dari masyarakat dalam bentuk simpanan dan menyalurkannya kepada masyarakat dalam bentuk kredit dan atau bentuk- bentuk lainnya dalam rangka meningkatkan taraf hidup rakyat banyak. Dengan kata lain, bank dalam menjalankan aktivitasnya berfungsi sebagai lembaga intermediasi (financial intermediary), yaitu lembaga keuangan yang berfungsi sebagai perantara pihak yang kelebihan dana dengan pihak yang kekurangan dana. Fungsi bank sebagai lembaga intermediasi ini membuat bank memiliki posisi yang strategis dalam perekonomian, pasalnya, dengan aktivitasnya, yaitu menghimpun dana dan menyalurkan dana kepada masyarakat yang membutuhkan akan meningkatkan arus dana untuk investasi, modal kerja maupun konsumsi. Sehingga akan dapat meningkatkan perekonomian nasional.

Dilihat dari tujuan perbankan syariah di atas, diperlukan berbagai terobosan baru di bidang perbankan untuk menggerakkan roda perekonomian Nasional. Sedangkan kondisi kesehatan maupun kinerja bank dapat kita analisis melalui laporan keuangan. Salah satu tujuan dari pelaporan keuangan adalah untuk memberikan informasi bagi para pengguna laporan keuangan untuk pengambilan keputusan. Kinerja keuangan suatu bank mencerminkan tingkat kesehatan bank.

Dalam Surat Edaran BI No. 9/24/DPbs disebutkan penilaian tingkat kesehatan bank dipengaruhi oleh faktor CAMELS (Capital, Asset Quality, Management, Earnings, Liquidity, Sensitivity to Market Risk). Aspek Capital meliputi Kewajiban Penyediaan Modal Minimum (KPMM) atau Capital Adequacy Ratio (CAR), aspek Asset Quality meliputi Non Performing Financing (NPF), aspek Earnings meliputi Return On Equity (ROE), Return On Asset (ROA), dan Operational Efficiency Ratio (BOPO).

Profitabilitas merupakan indikator yang paling tepat untuk mengukur kinerja suatu bank. Profitabilitas menggambarkan kemampuan perusahaan menghasilkan laba (Sofyan Syafri Harahap, 2002: 304). Rasio yang biasa digunakan untuk mengukur kinerja profitabilitas atau rentabilitas adalah Return On Equity (ROE) dan Return On Asset (ROA). ROE menunjukkan kemampuan manajemen bank dalam mengelola modal yang tersedia untuk mendapatkan net income, sedangkan ROA menunjukkan kemampuan 
manajemen bank dalam menghasilkan income dari pengelolaan aset yang dimiliki (Yuliani, 2007: 17). Berdasarkan pengertian tersebut dapat disimpulkan bahwa Return On Asset (ROA) ini memfokuskan pada kemampuan perusahaan untuk memperoleh pendapatan dalam operasi perusahaan, sedangkan Return on Equity (ROE) hanya mengukur return yang diperoleh dari investasi pemilik perusahaan dalam bisnis tersebut. Alasan dipilihnya Return On Asset (ROA) sebagai ukuran kinerja adalah karena ROA digunakan untuk mengukur kemampuan manajemen bank dalam memperoleh keuntungan secara Semakin tinggi rasionya, maka semakin baik pula dalam menggunakan asetnya (Lia Dwi Musyarofatun, 2012: 60).

Menurut Taswan, (2010: 166) bahwa Rasio Kecukupan Modal (CAR) merupakan perbandingan modal bank dengan ATMR. Semakin tinggi rasio Kecukupan Modal mengindikasikan bank tersebut semakin sehat permodalannya. Pemenuhan Kecukupan Modal minimum 8\% mengindikasikan bank mematuhi regulasi permodalan.

Besarnya modal suatu bank akan berpengaruh pada mampu atau tidaknya suatu bank secara efisien menjalankan kegiatannya. Jika modal yang dimiliki oleh bank tersebut mampu menyerap kerugian-kerugian yang tidak dapat dihindarkan, maka bank dapat mengelola seluruh kegiatannya secara efisien, sehingga kekayaan bank (kekayaan pemegang saham) diharapkan akan semakin meningkat demikian juga sebaliknya. Sehingga dapat disimpulkan bahwa hubungan antara kecukupan modal dengan profitabilitas (ROA) adalah positif. Rasio Efisiensi Operasional (BOPO) mengindikasikan efisiensi operasional bank. Semakin tinggi rasio Efisiensi Operasional, menunjukkan semmakin tidak efisien biaya operasional bank (Taswan, 2010: 166).

Edhi Satriyo Wibowo \& Muhammad Syaichu, (2013: 4) berpendapat bahwa Non Performing Financing (NPF) mencerminkan resiko pembiayaan, semakin tinggi rasio ini, menunjukkan kualitas pembiayaan bank syariah semakin buruk. Bertambahnya NPF akan mengakibatkan hilangnya kesempatan untuk memperoleh pendapatan dari pembiayaan yang diberikan sehingga mempengaruhi perolehan laba dan berpengaruh buruk pada profitabilitas (ROA).

Terjadi penurunan kualitas pembiayaan karena adanya pembiayaan lama dengan jumlah besar yang mengalami tunggakan hal ini mengakibatkan peningkatan pembiayaan yang macet. Adanya pembiayaan yang macet yang terjadi di awal tahun karena adanya pembiayaan yang belum terselesaikan, sementara ekspansi berjalan relatif lambat (Ratih Agustina, 2009: 1).

Kondisi perekonomian global turut mempengaruhi perlambatan kinerja perbankan syariah dalam negeri. Untuk menekan tingginya rasio pembiayaan yang macet, kalangan perbankan syariah akan lebih berhati-hati terutama dalam membiayai usaha berskala besar 
Tabel. 1 : Data Statistik Perbankan Syariah

\begin{tabular}{lrrrrrc}
\hline \multicolumn{1}{c}{ Indikator (\%) } & \multicolumn{1}{c}{$\mathbf{2 0 0 9}$} & \multicolumn{1}{c}{$\mathbf{2 0 1 0}$} & \multicolumn{1}{c}{$\mathbf{2 0 1 1}$} & \multicolumn{2}{c}{$\mathbf{2 0 1 2}$} & \multicolumn{1}{c}{$\mathbf{2 0 1 3}$} \\
\hline Profitabilitas (ROA) & 1,48 & 1,67 & 1,79 & 2,14 & 1,94 \\
Kecukupan modal (CAR) & 10,77 & 16,25 & 16,63 & 14,13 & 14,19 \\
Efisiensi operasional (BOPO) & 84,39 & 80,54 & 78,41 & 74,75 & 79,06 \\
Kualitas pembiayaan (NPF) & 4,01 & 3,02 & 2,52 & 2,22 & 2,96 \\
\hline
\end{tabular}

Sumber : Statistik Perbankan Syariah Oktober 2013

Menilik apa yang terjadi secara empiris tampak bahwa rasio-rasio keuangan Bank Syariah dari tahun ketahun mengalami perubahan dan terdapat penyimpangan dengan teori yang menyatakan hubungan kecukupan modal (CAR), efisiensi operasional (BOPO), dan kualitas pembiayaan (NPF) terhadap profitabilitas (ROA). Pada tahun 2012 ketika profitabilitas (ROA) naik menjadi 2, 14\%, kecukupan modal (CAR) justru mengalami penurunan sebesar 2, 5\% di tahun 2012. Namun sebaliknya ketika profitabilitas (ROA) turun masing-masing menjadi 1, 67\% dan 1, 79\% pada tahun 2010 dan 2011, kecukupan modal (CAR) justru naik masing-masing sebesar 5, 48\% dan 0, 38\% di tahun 2010 dan 2011. Pada tahun 2013 ketika kecukupan modal (CAR) naik sebesar $0,06 \%$ justru profitabilitas (ROA) mengalami penurunan sebesar $0,2 \%$. Hal ini bersimpangan dengan teori yang menyatakan bahwa kecukupan modal (CAR) berpengaruh positif terhadap profitabilitas (ROA).

Pada rasio efisiensi operasional (BOPO), dimana pada tahun 2012 di bulan juni efisiensi operasional (BOPO) sebesar 75, 74\% dengan profitabilitas (ROA) sebesar 2,05\%. Yang kemudian di bulan juli efisiensi operasional (BOPO) naik menjadi 75, 87\%, sedangkan rasio profitabilitas (ROA) nilainya tetap sebesar 2, 05\%. Sehingga bersimpangan dengan teori yang menyatakan semakin tinggi rasio Efisiensi Operasional, menunjukkan semakin tidak efisien biaya operasional bank.

Rasio kualitas pembiyaan (NPF) pun mengalami penyimpangan dengan teori yang ada. Ketika kualitas pembiyaan (NPF) pada tahun 2011 dan 2012 mengalami penurunan masing-masing sebesar 2, 52\% dan 2, 22\% profitabilitas (ROA) mengalami kenaikan masing-masing sebesar $0,12 \%$ dan 0 , 35\% di tahun 2011 dan 2012. Sehingga bersimpangan dengan teori yang menyatakan kualitas pembiyaan (NPF) tidak berpengaruh terhadap profitabilitas (ROA).

Kinerja keuangan Bank Syariah dari tahun ke tahun mengalami fluktuasi yang berdampak pada perolehan laba. Kondisi demikian menuntut perusahaan untuk selalu mengembangkan strategi perusahaan agar dapat 
bertahan atau bahkan berkembang lebih. Untuk itu perusahaan perlu mengembangkan suatu strategi yang tepat agar bisa mempertahankan eksistensinya dan memperbaiki kinerjanya, oleh karenanya salah satu langkah strategis yang dapat ditempuh oleh Bank Syariah agar tetap bertahan dan dipercaya oleh masyarakat adalah dengan meningkatkan kinerja keuangannya. Peningkatan kinerja keuangan mempunyai dampak yang luar biasa terhadap usaha menjaga kepercayaan nasabah agar tetap setia menggunakan jasanya. Dana yang telah dikumpulkan oleh bank Islam dari dana titipan pihak ketiga atau titipan lainnya, perlu dikelola dengan penuh amanah dan istiqomah. Dengan harapan dana tersebut mendatangkan keuntungan yang besar, baik untuk nasabah maupun bank Islam. Prinsip utama yang harus dikembangkan bank Islam dalam kaitan dengan manajemen dana adalah, bank Islam harus mampu memberikan bagi hasil kepada penyimpan dana minimal sama dengan atau lebih besar dari suku bunga yang berlaku di Bank Konvensional, dan mampu menarik bagi hasil dari debitur lebih rendah daripada bunga yang berlaku di Bank Konvensional (Muhammad, 2005: 107).

Dari fenomena gap di atas, dapat ditarik kesimpulan bahwa tidak setiap kejadian empiris sesuai dengan teori yang ada. Hal ini diperkuat oleh adanya research gap dalam penelitian-penelitian terdahulu. Sebagai contoh, dalam penelitian terdahulu, penelitian yang dilakukan oleh Yuliani (2007) menunjukkan bahwa kecukupan modal (CAR) dan efisiensi operasional (BOPO) berpengaruh signifikan terhadap ROA (Yuliani, 2007: 17).

Sedangkan penelitian yang dilakukan oleh Edhi Satriyo Wibowo dan Muhammad Syaichu (2013: 9) menunjukkan bahwa kecukupan modal (CAR) tidak memiliki pengaruh yang signifikan terhadap ROA, dan Efisiensi operasional (BOPO) memiliki pengaruh yang signifikan negatif terhadap ROA. Didukung oleh penelitian yang dilakukan oleh Moh. Sabir dkk. (2012: 85) yang menyatakan bahwa kecukupan modal (CAR) tidak berpengaruh terhadap profitabilitas (ROA), efisiensi operasional berpengaruh signifikan negatif terhadap profitabilitas (ROA), dan NPF tidak berpengaruh terhadap profitabilitas (ROA). Sedangkan dalam penelitian yang dilakukan oleh Bambang Agus Pramuka (2010) menyatakan Bahwa NPF berpengaruh signifikan negatif terhadap profitabilitas (ROA) (Bambang Agus Pramuka, 2010: 77).

Tujuan dari penelitian ini adalah untuk mengetahui apakah Kecukupan Modal (CAR), Efisiensi Operasional (BOPO), dan Kualitas Pembiayaan (NPF) mempunyai pengaruh yang signifikan terhadap profitabilitas (ROA) Bank Syariah di Indonesia tahun 2009-2013. 


\section{B. PEMBAHASAN}

\subsection{Pengertian Bank Syariah}

Pada umumnya yang dimaksud dengan bank syariah adalah lembaga keuangan yang usaha pokoknya memberikan kredit dan jasa-jasa lain dalam lalu lintas pembayaran serta peredaran uang yang beroperasi disesuaikan dengan prinsip-prinsip syariah (Heri Sudarsono, 2003: 27). Sedangkan menurut Undang-Undang No. 21 Tahun 2008 tentang Perbankan Syariah, Bank Syariah didefinisikan sebagai bank yang menjalankan kegiatan usahanya berdasarkan Prinsip Syariah dan menurut jenisnya terdiri atas Bank Umum Syariah dan Bank Pembiayaan Rakyat Syariah (Andri Soemitra, 2009: 61).

Bank syariah adalah bank yang dalam aktivitasnya, baik penghimpunan dana maupun dalam rangka penyaluran dananya memberikan dan mengenakan imbalan atas dasar prinsip syariah yaitu jual beli dan bagi hasil (Totok Budi Santoso \& Sigit Triandaru, 2006: 153). Menurut Muhammad (2005: 1) bahwa bank syariah adalah bank yang beroperasi dengan tidak mengandalkan pada bunga. Bank Islam atau biasa disebut dengan bank tanpa bunga adalah lembaga keuangan/perbankan yang operasional dan produknya dikembangkan berlandaskan pada Al-Quran dan Hadist Nabi SAW. Dengan kata lain bank syariah adalah lembaga keuangan yang usaha pokoknya memberikan pembiayaan dan jasa-jasa lainnya dalam lalulintas pembayaran serta peredaran uang yang pengoperasiannya berdasarkan syariat Islam. Bank syariah adalah bank yang dalam menjalankan usahanya berdasarkan pada prinsip-prinsip hukum atau syariah Islam dengan mengacu kepada al-Qur'an dan al-Hadis (Moh Rifai, 2002: 11).

\subsection{Sumber- Sumber Dana Bank Syariah}

Zainul Arifin mengatakan bahwa sumber dana bank syariah terdiri dari: a. Modal inti (core capital)

Modal inti adalah dana modal sendiri yaitu dana yang berasal dari para pemegang saham bank, yakni pemilik bank. Pada umumnya dana modal inti terdiri dari:

1) Modal yang disetor oleh para pemegang saham.

2) Cadangan, yaitu sebagian laba bank yang tidak dibagi, yang disisihkan untuk menutup timbulnya risiko kerugian di kemudian hari.

3) Laba ditahan, yaitu sebagian laba yang seharusnya dibagikan kepada para pemegang saham, tetapi oleh para pemegang saham sendiri diputuskan untuk ditanam kembali dalam bank.

b. Kuasi ekuitas (mudharabah account)

Bank menghimpun dana berbagi hasil atas dasar prinsip mudharabah, yaitu akad kerjasama antara pemilik dana (shahib al maal) dengan pengusaha (mudharib) untuk melakukan suatu usaha bersama, dan pemilik dana tidak boleh mencampuri pengelolaan bisnis sehari-hari. 
Berdasarkan prinsip ini, bank menyediakan jasa bagi investor berupa:

1) Rekening investasi umum, dimana bank menerima simpanan dari nasabah yang mencari kesempatan investasi atas dana mereka dalam bentuk investasi berdasarkan prinsip mudharabah mutlaqah (unrestricted investment account). Dalam hal ini bank bertindak sebagai mudharib dan nasabah bank bertindak sebagai Shahib al Maal, sedang keduanya menyepakati pembagian laba (bila ada) yang dihasilkan dari penanaman dana tersebut dengan nisbah tertentu. Dalam hal terjadi kerugian, nasabah menanggung kerugian tersebut dan bank kehilangan keuntungan.

2) Rekening investasi khusus, dimana bank bertindak sebagai manajer investasi bagi nasabah institusi (pemerintah atau lembaga keuangan lain) atau nasabah korporasi untuk menginvestasikan dana mereka pada unitunit usaha atau proyek-proyek tertentu yang mereka setujui atau mereka kehendaki.

3) Rekening tabungan mudharabah. Dalam aplikasinya bank syariah melayani tabungan mudharabah dalam bentuk targeted saving, seperti tabungan korban, tabungan haji atau tabungan lain yang dimaksudkan untuk suatu pencapaian target kebutuhan dalam jumlah dan atau jangka waktu tertentu.

c. Dana titipan (wadi'ah / non remunerated deposit)

Dana titipan adalah dana pihak ketiga yang dititipkan pada bank, yang umumnya berupa giro atau tabungan. Menurut Zainul Arifin, dana titipan ini dikembangkan dalam bentuk berikut:

1) Rekening giro wadi'ah

Dalam hal ini bank menggunakan prinsip wadiah yad dhamanah. Dengan prinsip ini bank sebagai custodian harus menjamin pembayaran kembali nominal simpanan wadi'ah. Dana tersebut dapat digunakan oleh bank untuk kegiatan komersial dan bank berhak atas pendapatan yang diperoleh dari pemanfaatan harta titipan tersebut dalam kegiatan komersial.

2) Rekening tabungan wadi'ah

Dalam hal ini nasabah dapat menarik sebagian atau seluruh saldo simpanannya sewaktu-waktu atau sesuai dengan perjanjian yang disepakati. Bank menjamin pembayaran kembali simpanan mereka. Semua keuntungan atas pemanfaatan dana tersebut adalah milik bank, tetapi, atas kehendaknya sendiri, bank dapat memberikan imbalan keuntungan yang berasal dari sebagian keuntungan bank. Bank menyediakan buku tabungan dan jasa-jasa yang berkaitan dengan rekening tersebut.

\subsection{Prinsip-Prinsip Bank Syariah}

Adapun prinsip-prinsip perbankan syari'ah adalah sebagai berikut: 
a. Prinsip Simpanan Murni

Prinsip simpanan murni merupakan fasilitas yang diberikan oleh bank Islam untuk memberikan kesempatan kepada pihak yang kelebihan dana untuk menyimpan dananya dalam bentuk Al Wadi'ah. Fasilitas Al Wadi'ah biasa diberikan untuk tujuan investasi guna mendapatkan keuntungan seperti halnya tabungan dan deposito.

b. Bagi Hasil

Sistem ini adalah suatu sistem yang meliputi tata cara pembagian hasil usaha antara penyedia dana dengan pengelola dana. Pembagian hasil usaha ini dapat terjadi antara bank dengan penyimpan dana, maupun antara bank dengan nasabah penerima dana. Bentuk produk yang berdasarkan prinsip ini adalah mudharabah dan musyarakah. Lebih jauh prinsip mudharabah dapat dipergunakan sebagai dasar baik untuk produk pendanaan (tabungan dan deposito) maupun pembiayaan, sedangkan musyarakah lebih banyak untuk pembiayaan.

c. Prinsip Jual Beli dan Margin Keuntungan

Prinsip ini merupakan suatu sistem yang menerapkan tata cara jual beli, di mana bank akan membeli terlebih dahulu barang yang di butuhkan atau mengangkat nasabah sebagai agen bank melakukan pembelian barang atas nama bank, kemudian bank menjual barang tersebut kepada nasabah dengan harga sejumlah harga beli di tambah keuntungan (Margin/Mar- up).

d. Prinsip Sewa

Prinsip ini secara garis besar terbagi kepada 2 jenis :

1) Ijarah, sewa murni, seperti halnya penyewaan traktor dan alat-alat produk lainnya (operating lease). Dalam teknis perbankan, bank dapat membeli dahulu yang di butuhkan nasabah kemudian menyewakan dalam waktu dan hanya yang telah di sepakati kepada nasabah.

2) Bai al takjiri atau ijarah al muntahiya bit tamlik merupakan penggabungan sewa dan beli, di mana si penyewa mempunyai hak untuk memiilliki barang pada akhir masa sewa (financial lease).

e. Prinsip Fee (Jasa)

Prinsip ini meliputi seluruh layanan non pembiayaan yang diberikan bank (Muhamma \& Dwi Suwiknyo, 2009: 10-11).

\subsection{Dasar Hukum Operasional Bank Syariah}

Undang-undang nomor 7 tahun 1992 tentang perbankan, memang tidak ada aturan tentang bank umum syariah, karena dalam undang-undang tersebut hanya menjelaskan tentang perbankan konvensional, kecuali pasal 13 menyatakan DPR bagi hasil.

Menurut Heri Sudarsono, (2003 : 31-32) bahwa bank umum syari'ah didirikan pertama di Indonesia tahun 1992 berdasarkan UU No. 7 Th. 1992 tentang perbankan dan Peraturan Pemerintah No. 72 Th. 1992, tentang bank beroperasi berdasarkan 
prinsip bagi hasil sedangkan sebagai landasan hukum BPRS adalah UU No. 7 Th. 1992 tentang perbankan dan PP No. 73 tentang DPR beropersi berdasarkan prinsip bagi hasil.

Namun pengaturan mengenai perbankan syariah didalam Undang- Undang Nomor 7 Tahun 1992 tentang Perbankan sebagaimana telah diubah dengan Undang-Undang Nomor 10 Tahun 1998 belum spesifik sehingga perlu diatur secara khusus dalam suatu undang-undang tersendiri dengan dikeluarkan dikeluarkannya Undang-Undang Nomor 21 Tahun 2008. Dalam UU No. 21 Tahun 2008 Pasal (5) untuk memperoleh izin usaha Bank Syariah harus memenuhi persyaratan sekurang-kurangnya tentang: Susunan organisasi dan kepengurusan, permodalan, kepemilikan, keahlian dibidang perbankan syariah, dan kelayakan usaha. Menurut Pasal (9) Bank Umum Syariah hanya dapat didirikan dan/atau dimiliki oleh :

a. Warga negara Indonesia atau badan hukum Indonesia.

b. Warga negara Indonesia atau badan hukum Indonesia dengan warga negara asing atau badan hukum asing secara kemitraan.

c. Pemerintah daerah (Rachmadi Usman, 2009: 391-393).

\subsection{Fungsi Dan Tujuan Bank Syariah}

Menurut Muhammad Syafi'i Antonio, (2001: 201-202) bahwa dalam paradigma akuntansi Islam, bank syariah memiliki fungsi sebagai berikut:

a. Manajemen investasi, bank syariah dapat melaksanakan fungsi ini berdasarkan kontrak mudharabah atau kontrak perwakilan.

b. Investasi, bank syariah menginvestasikan dana yang ditempatkan pada dunia usaha (baik dana modal maupun dana rekening investasi) dengan menggunakan alat-alat investasi yang konsisten dengan syariah.

c. c. Jasa-jasa keuangan, bank syariah dapat menawarkan berbagai jasa keuangan lainnya berdasarkan upah (fee based) dalam sebuah kontrak perwakilan suatu penyewaan. Contoh: garansi, transfer, Letter Of Credit, dll.

d. Jasa sosial, konsep perbankan syariah mengharuskan bank syariah melaksanakan jasa sosial, bisa melalui dana qardh (pinjaman kebajikan), zakat, atau dana sosial yang sesuai dengan ajaran Islam.

Tujuan didirikannya Bank Syariah adalah sebagai berikut (Warkum Sumitro, 1996: 17-18) :

a. Mengarahkan kegiatan ekonomi umat untuk bermuamalah secara Islam.

b. Menciptakan suatu keadilan di bidang ekonomi.

c. Meningkatkan kualitas hidup umat.

d. Membantu menanggulangi masalah kemiskinan.

e. Menjaga kestabilan ekonomi/moneter pemerintah. 
f. Menyelamatkan ketergantungan umat Islam terhadap bank konvensional, yang menyebabkan umat Islam berada di bawah kekuasaan bank.

\subsection{Laporan Keuangan}

Laporan keuangan menggambarkan kondisi keuangan dan hasil usaha suatu perusahaan pada saat tertentu atau jangka waktu tertentu. Adapun jenis laporan keuangan yang lazim dikenal adalah : Neraca, Laporan Laba/Rugi, Laporan Arus Kas, Laporan Perubahan Posisi Keuangan (Sofyan Syafri Harahap, 2002: 105).

Laporan keuangan bank syariah terdiri dari:

a. Laporan Posisi Keuangan (Neraca)

Neraca mencakup asset, liabilitas, equity dari pemilik rekening investasi tidak terbatas dan sejenisnya, dan modal pemilik pada suatu tanggal yang harus diungkapakan.

b. Laporan Laba Rugi

Laporan laba rugi mencakup pendapatan investasi, biaya-biaya, keuntungan atau kerugian yang harus diungkapkan berdasarkan jenisnya selama periode yang dicakup oleh laporan laba rugi.

c. Laporan Arus Kas

Laporan arus kas harus membedakan antara arus kas dari operasi, arus kas dari kegiatan investasi dan arus kas dari kegiatan pembiayaan.

d. Laporan Perubahan Modal Pemilik (Laporan Laba ditahan)

Periode yang dicakup oleh Laporan Perubahan Modal Pemilik (Laporan Laba ditahan) harus diungkapkan. Laporan tersebut harus mengungkapkan hal-hal sebagai berikut :

1) Modal disetor

2) Kontribusi modal para pemilik selama periode

3) Pendapatan (kerugian) netto selama periode

4) Distribusi kepada para pemilik selama periode

5) Kenaikan/penurunan pada cadangan legal dan pilihan selama periode

6) Laba ditahan pada awal periode dengan pengungkapan terpisah mengenai jumlah laba ditahan yang dperkirakan.

e. Laporan Perubahan Pada Investasi Terbatas

Laporan ini harus memisahkan investasi terbatas berdasarkan sumber pembiayaan dan memisahkan portofolio investasi berdasarkan jenisnya.

f. Laporan Sumber-Sumber dan Penggunaan Dana Zakat dan Sumbangan Pengungkapan harus dilakukan untuk dana-dana yang dibayarkan oleh bank dari dana zakat dan sumbangan selama periode dan dana-dana yang tersedia pada akhir periode.

g. Laporan Sumber-Sumber dan Penggunaan Dana Qard 
Adalah laporan yang mengungkapkan sumber-sumber dan penggunaan dana Qard pada suatu periode tertentu.

h. Catatan-Catatan Laporan Keuangan

Laporan keuangan harus mengungkapkan semua informasi dan material yang perlu untuk menjadikan laporan keuangan tersebut memadai, relevan dan bisa dipercaya bagi para pemakainya.

Secara umum tujuan pembuatan laporan keuangan suatu bank adalah sebagai berikut (Kasmir, 2002: 173-174) :

1) Memberikan informasi keuangan tentang jumlah aktiva, kewajiban dan modal bank pada waktu tertentu.

2) Memberikan informasi tentang hasil usaha yang tercermin dari pendapatan yang diperoleh dan biaya-biaya yang dikeluarkan dalam periode tertentu.

3) Memberikan informasi tentang perubahan-perubahan yang terjadi dalam aktiva, kewajiban, dan modal suatu bank.

4) Memberikan informasi tentang kinerja manajemen bank dalam suatu periode.

\subsection{Rasio Keuangan}

Rasio keuangan adalah angka yang diperoleh dari hasil perbandingan dari suatu pos laporan keuangan dengan pos lainnya yang mempunyai hubungan yang relevan dan signifikan (Sofyan Syafri Harahap, 2002: 299). Rasio keuangan pada dasarnya disusun dengan menggunakan angka- angka di dalam atau antara laporan laba-rugi dan neraca (Mamduh M. Hanafi \& Abdul Halim, 2007: 74).

Dengan menggunakan alat analisa laporan berupa rasio keuangan dapat menjelaskan dan memberikan gambaran kepada penganalisa tentang baik buruknya keadaan atau posisi keuangan suatu perusahaan dari satu periode ke periode berikutnya.

Dalam penelitian ini akan digunakan 4 (empat) golongan rasio, secara khusus, yaitu menggunakan rasio kecukupan modal, efisiensi operasional, kualitas pembiayaan dan profitabilitas.

\section{a. Kecukupan Modal (Capital Adequacy Ratio / CAR)}

Kecukupan modal (Capital Adequacy Ratio / CAR) adalah rasio yang memperlihatkan seberapa besar jumlah seluruh aktiva bank yang mengandung unsur risiko (kredit, penyertaan, surat berharga, tagihan pada bank lain) yang ikut dibiayai dari modal sendiri disamping memperoleh dana-dana dari sumbersumber diluar bank (Yuliani, 2007: 25).

Rasio Kecukupan modal (Capital Adequacy Ratio/CAR) merupakan perbandingan modal bank dengan ATMR. Semakin tinggi rasio kecukupan modal mengindikasikan bank tersebut semakin semakin sehat permodalannya. Pemenuhan kecukupan modal minimum 8\% mengindikasikan bank mematuhi regulasi permodalan (Taswan, 2010: 166). 


\section{b. Efisiensi Operasional (Biaya Operasional/Pendapatan Operasional/BOPO)}

Efisiensi Operasional diukur dengan menggunakan BOPO yaitu, rasio perbandingan antara Biaya Operasional dengan Pendapatan Operasional, semakin rendah tingkat rasio Efisiensi Operasional (Biaya Operasional/ pendapatan operasional/BOPO) berarti semakin baik kinerja manajemen bank tersebut, karena lebih efisien dalam menggunakan sumber daya yang ada di perusahaan (Taswan, 2010: 167). Rasio efisiensi operasional (Biaya Operasional/pendapatan operasional/BOPO) menunjukkan efisiensi bank dalam menjalankan usaha pokoknya terutama kredit, dimana bunga kredit menjadi pendapatan terbesar perbankan (Edhi Satriyo Wibowo \& Muhammad Syaichu, 2013: 4).

Rasio ini sering disebut rasio efisiensi digunakan untuk mengukur kemampuan manajemen bank dalam mengendalikan biaya operasional terhadap pendapatan operasional. Semakin kecil rasio ini berarti semakin efisien biaya operasional yang dikeluarkan bank yang bersangkutan sehingga kemungkinan suatu bank dalam kondisi bermasalah semakin kecil. Biaya operasional dihitung berdasarkan penjumlahan dari total beban bunga dan total beban operasional lainnya. Pendapatan operasional adalah penjumlahan dari total pendapatan bunga dan total pendapatan operasional lainnya (Yuliani, 2007:35).

\section{c. Kualitas Pembiayaan (diukur dengan Non Performing Financing/ NPF)}

Salah satu perhitungan kinerja keuangan Bank Syariah menurut Peraturan Bank Indonesia No. 9/1/PBI/2007 tentang Sistem Penilaian Tingkat Kesehatan Bank Umum Berdasarkan Prinsip Syariah, adalah dengan kualitas pembiayaan Bank Syariah. Penilaian kualitas asset merupakan penilaian terhadap kondisi asset Bank/UUS dan kecukupan manajemen resiko pembiayaan. Penilaian kualitas asset dimaksudkan untuk menilai kondisi asset Bank, termasuk antisipasi resiko gagal bayar dari pembiayaan yang akan muncul. Penyaluran dana berdasarkan prinsip syariah oleh Bank Syariah dan UUS mengandung risiko kegagalan atau kemacetan dalam pelunasannya sehingga dapat berpengaruh terhadap kesehatan bank syariah dan UUS (Zubairi Hasan, 2009: 115).

Rasio yang digunakan untuk mengukur tingkat bermasalahnya suatu kredit atau pembiayaan biasanya adalah rasio aktiva produktif yaitu rasio NPF. NPF (Non Performing Financing) adalah perbandingan antara pembiayaan bermasalah terhadap total pembiayaan. Rasio ini mengindikasikan bahwa semakin tinggi rasio NPF (Non Performing Financing) menunjukkan semakin buruk kualitas pembiayaannya (Taswan, 2010: 166).

NPF (Non Performing Financing) merupakan salah satu penilaian kuantitatif faktor kualitas asset. NPF bertujuan untuk mengukur tingkat permasalahan pembiayaan yang tingkat permasalahan pembiayaan yang dihadapi oleh bank. Semakin tinggi rasio ini, menunjukkan kualitas pembiayaan Bank Syariah semakin 
buruk yang menyebabkan jumlah pembiayaan bermasalah semakin besar maka kemungkinan suatu bank dalam kondisi bermasalah semakin besar.

\section{d. Profitabilitas}

Rasio profitabilitas digunakan untuk mengukur kemampuan perusahaan menghasilkan keuntungan pada tingkat penjualan, asset, dan modal saham yang tertentu (Mamduh M. Hanafi \& Abdul Halim, 2007: 81).

Rasio Profitabilitas menggambarkan kemampuan perusahaan mendapatkan laba melalui semua kemampuan perusahaan mendapatkan laba melalui semua kemampuan, dan sumber yang ada seperti kegiatan penjualan, kas, modal, jumlah karyawan, jumlah cabang dan sebagainya (Sofyan Syafri Harahap, 2002: 304).

Profitabilitas adalah kenaikan bersih dari asset bersih sebagai akibat dari memegang asset yang mengalami peningkatan nilai selama periode yang dipilih oleh pernyataan pendapatan (Muhammad Syafi'i Antonio, 2001: 205). Ada dua rasio yang biasanya dipakai untuk mengukur profitabilitas bank yaitu return on asset (ROA) dan return on equity (ROE). ROA adalah perbandingan antara pendapatan bersih (net income) dengan rata-rata aktiva (average assets).

\subsection{Metode Penelitian}

Jenis penelitian ini merupakan jenis penelitian kepustakaan (Library Research), yang digunakan untuk mendapatkan data sekunder, yaitu pencarian bahan-bahan dan teori-teori dengan mempelajari, meneliti, mengkaji, serta menelaah literatur-literatur yang berhubungan dengan masalah yang akan diteliti. Dalam penelitian ini terdapat tiga variabel bebas yaitu kecukupan modal (CAR), efisiensi operasional (BOPO), dan kualitas pembiayaan (NPF). Sedangkan variabel terikatnya, yaitu profitabilitas (ROA). Sedangkan pendekatan penelitian ini menggunakan pendekatan kuantitatif yaitu metode penelitian yang berlandaskan pada filsafat positivisme, digunakan untuk meneliti pada populasi / sampel tertentu.

Dalam melaksanakan penelitian ini, data yang dipergunakan adalah data sekunder yang berupa rasio keuangan masing-masing perusahaan perbankan di Indonesia. Yaitu data yang sudah tersedia dan dikumpulkan oleh pihak lain. 3 Data yang digunakan dalam penelitian ini merupakan data sekunder yang diperoleh dari Laporan Keuangan Publikasi Triwulanan yang diterbitkan oleh Bank Umum Syariah dalam website resmi Bank Indonesia dan website resmi masing-masing bank. Periodesasi data menggunakan data Laporan Keuangan triwulan beberapa Bank Umum Syariah, yaitu Bank Syariah Mandiri, Bank Syariah BRI, dan Bank Syariah Mega Indonesia yang dipublikasikan selama tahun 2009-2013.

Populasi yang digunakan dalam penelitian ini adalah seluruh Bank Umum Syariah yang terdapat di Indonesia hingga tahun 2013. Jumlah Bank Umum Syariah yang ada hingga tahun 2013 sebanyak 11 bank. Diantaranya : PT. Bank Syariah Mandiri, PT. Bank Mua'malat Indonesia, PT. Bank Syariah BNI, PT. Bank 
Syariah BRI, PT. Bank Syariah Mega Indonesia, PT. Bank Jabar dan Banten, PT. Bank Panin Syariah, PT. Bank Syariah Bukopin, PT. Bank Victoria Syariah, PT. BCA Syariah, PT. Maybank Indonesia Syariah.

Teknik pengambilan sampel (sampling) adalah cara peneliti mengambil sampel atau contoh yang representatif dari populasi yang tersedia. 5 Sampel penelitian diambil secara purposive sampling, karena perusahaan perbankan yang menjadi sampel disini mampu memberikan informasi yang dibutuhkan bagi penelitian ini, dimana, sampel digunakan apabila memenuhi kriteria yang ditunjukkan sebagai berikut:

Tabel 2: Kriteria Penentuan Sampel

\begin{tabular}{|l|c|}
\hline \multicolumn{1}{|c|}{ Kriteria Jumlah Bank } & Jumlah Bank \\
\hline a. Bank Umum Syariah di Indonesia & 11 \\
\hline $\begin{array}{l}\text { b. Bank yang diteliti masih beroperasi pada periode waktu } \\
\text { penelitian }\end{array}$ & 11 \\
\hline $\begin{array}{l}\text { c. Tersedia laporan keuangan triwulanan pada periode 2009- } \\
\mathbf{2 0 1 3} \text { secara lengkap }\end{array}$ & 3 \\
\hline d. Bank yang diteliti sudah beroperasi lebih dari 5 th tahun & 3 \\
\hline
\end{tabular}

Sumber: Laporan Perkembangan Perbankan Syariah

Berdasarkan kriteria dalam table. 2 di atas, maka sampel yang digunakan dalam penelitian ini ada 3 Bank Umum Syariah yaitu:

Tabel 3: Daftar sampel penelitian

\begin{tabular}{|c|l|}
\hline No. & \multicolumn{1}{|c|}{ Nama Bank } \\
\hline $\mathbf{1 .}$ & PT. Bank Syariah Mandiri \\
\hline $\mathbf{2}$. & PT. Bank Syariah BRI \\
\hline 3. & PT. Bank Syariah Mega Indonesia \\
\hline
\end{tabular}

Penelitian ini menggunakan uji asumsi klasik dengan analisis regresi berganda:

$$
Y=a+b_{1} x_{1}+b_{2} x_{2}+b_{3} x_{3}+e
$$

Dimana: $Y \quad$ : Profitabilitas

$$
\begin{array}{ll}
\text { a } & \text { : Konstanta } \\
\text { x1 } & \text { : Kecukupan Modal } \\
\text { x2 } & : \text { Efisiensi Operasional } \\
\text { x3 } & : \text { Kualitas Pembiayaan } \\
\text { b1 } & \text { : Koefisien regresi variabel Kecukupan Modal }
\end{array}
$$


b2 : Koefisien regresi variabel Efisiensi Operasional

b3 : Koefisien regresi variabel Kualitas Pembiayaan

e : Pengganggu (eror).

\section{9 Hasil Penelitian dan Pembahasan}

Hasil pengujian hipotesis dalam penelitian ditunjukkan oleh table berikut:

Tabel 4 : Hasil Uji Hipotesis

\begin{tabular}{|c|c|c|c|c|c|}
\hline \multirow[t]{2}{*}{ Model } & \multicolumn{2}{|c|}{$\begin{array}{l}\text { Unstandardized } \\
\text { Coefficients }\end{array}$} & \multirow{2}{*}{$\begin{array}{c}\begin{array}{r}\text { Standardized } \\
\text { Coefficients }\end{array} \\
\text { B }\end{array}$} & \multirow[t]{2}{*}{$\mathbf{t}$} & \multirow[t]{2}{*}{ Sig. } \\
\hline & B & Std. Error & & & \\
\hline \multirow{4}{*}{$\begin{array}{l}1 \\
\text { (Constant) } \\
\text { CAR } \\
\text { BOPO } \\
\text { NPF }\end{array}$} & 8. 379 & 1. 001 & & 8.369 & .000 \\
\hline & .023 & .023 & .138 & 1. 000 & .322 \\
\hline & -.079 & .011 & -.767 & -6.900 & .000 \\
\hline & -.047 & .109 & -.057 & -.435 & .666 \\
\hline
\end{tabular}

a. Dependent Variable: ROA (Y)

Sumber: Data Sekunder Diolah

Dalam penelitian ini menggunakan rumus persamaan regresi ganda sebagai berikut:

$$
\begin{aligned}
& Y=a+b_{1} X_{1}+b_{2} X_{2}+b_{3} X_{3}+e \\
& Y=8,379+0,023 X_{1-0}, 079 X_{2}-0,047 X_{3}+e
\end{aligned}
$$

Berdasarkan persamaan regresi linear berganda di atas, maka dapat di interprestasikan sebagai berikut:

a. Nilai Konstanta sebesar 8, 379 menyatakan bahwa jika variabel independen dianggap konstan, maka rata-rata tingkat Profitabilitas (ROA) adalah 8, 379.

b. b. Koefisien regresi X1 (CAR) dari perhitungan linier berganda dapat dilihat 0 , 023. Hal ini berarti setiap ada peningkatan $1 \%$ maka tingkat Profitabilitas (ROA) akan meningkat sebesar 0, $023 \%$.

c. Koefisien regresi $X_{2}$ Efisiensi Operasional (BOPO) sebesar -0, 079. Hal ini berarti setiap ada peningkatan $1 \%$ maka tingkat Profitabilitas (ROA) akan mengalami penurunan sebesar 0, $079 \%$.

d. Koefisien regresi $\mathrm{X}_{3}$ Kualitas Pembiayaan (NPF) dari perhitungan linier berganda dapat dilihat $-0,047$. Hal ini berarti setiap ada peningkatan $1 \%$ maka tingkat Profitabilitas (ROA) akan turun sebesar 0, 047 \%. 


\section{1) Pengaruh Kecukupan Modal (CAR) Terhadap Tingkat Profitabilitas (ROA) Bank Syariah}

Dapat diketahui bahwa variabel Kecukupan Modal (CAR) sebagai variabel independent $\left(\mathrm{X}_{1}\right)$ menunjukkan tidak memiliki pengaruh yang signifikan terhadap profitabilitas (ROA) (Y) Bank Syariah Tahun 2009-2013. Hal ini dapat dilihat pada hasil uji parsial untuk variabel $X_{1}$ (CAR) diperoleh thitung sebesar 1, 000 dengan signifikansi 0 , 322. Sedangkan ttabel dengan $\mathrm{df}=56$ diperoleh nilai sebesar 2, 003. Sehingga thitung $<$ tabel $(1,000<2,003)$ dan Nilai signifikansi lebih besar dari 0, $05(0,322>0,05)$. Berdasarkan hasil tersebut hipotesis pertama (H1) dalam penelitian ini yaitu Kecukupan Modal (CAR) tidak memiliki pengaruh yang signifikan terhadap tingkat profitabilitas (ROA) Bank Syariah ditolak dan menerima $\left(\mathrm{H}_{\mathrm{O}}\right)$.

Hasil ini tidak konsisten dengan hasil penelitian Yuliani (2007), dan Bambang Sudiyatno (2010) yang keduanya menyatakan bahwa Kecukupan Modal (CAR) berpengaruh terhadap profitabilitas. Kecukupan Modal (CAR) digunakan untuk mengukur seberapa besar jumlah seluruh aktiva bank yang mengandung unsur resiko (kredit, penyertaan, surat berharga, tagihan pada bank lain).

Tidak berpengaruhnya Kecukupan Modal (CAR) terhadap profitabilitas antara lain disebabkan karena bank-bank yang beroperasi tidak mengoptimalkan modal yang ada. Sejalan dengan semakin bertambahnya modal tidak diikuti oleh penyaluran pembiayaan kepada unit usaha produktif. Hal ini terjadi karena peraturan Bank Indonesia yang mensyaratkan CAR minimal sebesar $8 \%$ yang mengakibatkan Bank Syariah selalu berusaha menjaga agar CAR yang dimilikinya sesuai dengan ketentuan. Sehingga profitabilitas yang diperoleh kurang optimal.

\section{2) Pengaruh Efisiensi Operasional (BOPO) Terhadap Tingkat Profitabilitas (ROA) Bank Syariah}

Dapat diketahui bahwa variabel BOPO sebagai variabel independen $\left(\mathrm{X}_{2}\right)$ menunjukkan terdapat pengaruh yang signifikan terhadap tingkat profitabilitas (ROA) (Y) Bank Syariah Tahun 2009-2013. Hal ini dapat diketahui bahwa uji parsial untuk variabel (X2) Efisiensi Operasional (BOPO) diperoleh thitung sebesar 6, 900 dengan signifikansi 0,000 . Sedangkan tabel dengan $\mathrm{df}=56$ diperoleh nilai sebesar 2,003. Sehingga thitung $>$ tabel $(6,900>2,003)$ dan Nilai signifikansi kurang dari 0, $05(0,000<0,05)$. Berdasarkan hasil tersebut hipotesis kedua $\left(\mathrm{H}_{2}\right)$ diterima, dan menolak $\left(\mathrm{H}_{0}\right)$ yaitu BOPO berpengaruh dan signifikan terhadap tingkat profitabilitas (ROA) Bank Syariah.

Hasil ini konsisten dengan hasil penelitian Yuliani (2007), Edhi Satriyo Wibowo (2013), dan Sabir dkk. (2012), yang menyatakan bahwa efisiensi operasional yang diukur dengan BOPO berpengaruh terhadap profitabilitas 
(ROA). BOPO digunakan untuk mengukur tingkat efisiensi dan kemampuan bank dalam melakukan kegiatan operasinya.

BOPO berpengaruh terhadap profitabilitas Bank Syariah dikarenakan Bank Syariah tersebut mampu mengelola biaya operasionalnya dengan efisien, sehingga profitabilitas yang diperoleh Bank Syariah dapat optimal. Dengan kata lain antara pendapatan yang diperoleh dengan pengeluaran lebih besar pendapatan.

\section{3) Pengaruh Kualitas Pembiayaan (NPF) Terhadap Tingkat Profitabilitas (ROA) Bank Syariah}

Dapat diketahui bahwa variabel Kualitas Pembiayaan (NPF) sebagai variabel independen $\left(\mathrm{X}_{3}\right)$ menunjukkan tidak berpengaruh signifikan terhadap tingkat profitabilitas (ROA) (Y) pada Bank Syariah Tahun 2009 - 2013. Hal ini dapat diketahui bahwa uji parsial untuk variabel kualitas pembiayaan (NPF) (X3) diperoleh thitung sebesar 0,435 dengan signifikansi 0,666. Sedangkan ttabel dengan $\mathrm{df}=56$ diperoleh nilai sebesar 2, 003. Sehingga thitung $<$ tabel $(0$, $435<2$, 003) dan Nilai signifikansi lebih besar dari 0, 05 (0, $666>0,05)$. Berdasarkan hasil tersebut hipotesis ketiga $\left(\mathrm{H}_{3}\right)$ dalam penelitian ini yaitu kualitas pembiayaan (NPF) berpengaruh negatif dan tidak signifikan terhadap tingkat profitabilitas (ROA) terhadap tingkat profitabilitas (ROA) Bank Syariah ditolak dan menerima $\left(\mathrm{H}_{\mathrm{O}}\right)$.

Tidak berpengaruhnya Kualitas Pembiayaan (NPF) terhadap tingkat profitabilitas (ROA) disebabkan karena kondisi Kualitas Pembiayaan (NPF) yang lebih besar dalam satu periode tidak secara langsung memberikan penurunan laba pada periode yang sama. Manakala bank memiliki jumlah pembiayaan macet yang tinggi, maka bank akan berusaha terlebih dahulu mengevaluasi kinerja mereka dengan sementara menghentikan penyaluran pembiayaan hingga Kualitas Pembiayaan (NPF) berkurang. Dari data yang diperoleh, Kualitas Pembiayaan (NPF) Bank Syariah relatif kecil atau sedikit yang macet. Sehingga dapat disimpulkan bahwa Kualitas Pembiayaan (NPF) tidak mempengaruhi tingkat profitabilitas (ROA) bank syariah. Hal yang sama ditunjukkan oleh penelitian Edhi Satriyo Wibowo (2013), Sabir dkk. (2012), yang menyatakan bahwa NPF tidak berpengaruh terhadap profitabilitas (ROA).

\section{KESIMPULAN}

Berdasarkan hasil penelitian dan pembahasan di atas dapat ditarik kesimpulan sebagai berikut:

a. Tidak ada pengaruh yang signifikan antara Kecukupan Modal (CAR) terhadap profitabilitas (ROA) Bank Syariah tahun 2009-2013 dengan variabel $\mathrm{X}_{1}$ kecukupan modal (CAR) diperoleh thitung sebesar 1, 000 dengan signifikansi 0,322 . Sedangkan ttabel dengan $\mathrm{df}=56$ diperoleh nilai sebesar 2 , 
003. Sehingga thitung $<$ tabel $(1,000<2$, 003) dan Nilai signifikansi lebih besar dari 0, $05(0,322>0,05)$ maka kesimpuannya $\mathrm{H} 0$ diterima dan menolak H1. Jadi, $X_{1}$ (CAR) berpengaruh negatif dan tidak signifikan terhadap profitabilitas (ROA) (Y) Bank Syariah Tahun 2009-2013.

b. Terdapat pengaruh yang signifikan antara Efisiensi Operasional (BOPO) terhadap profitabilitas (ROA) Bank Syariah tahun 2009-2013 dengan variabel X2 (BOPO) diperoleh thitung sebesar 6, 900 dengan signifikansi 0, 000. Sedangkan ttabel dengan $\mathrm{df}=56$ diperoleh nilai sebesar 2, 003. Sehingga thitung > ttabel $(6,900>2,003)$ dan Nilai signifikansi kurang dari 0, 05 (0, $000<0$, 05) maka kesimpuannya H0 ditolak dan menerima H2. Jadi X2 (BOPO) berpengaruh signifikan terhadap profitabilitas (ROA) (Y) Bank Syariah Tahun 2009-2013.

c. Tidak ada pengaruh yang signifikan antara Kualitas Pembiayaan (NPF) Bank Syariah tahun 2009-2013, dengan variabel NPF (X3) diperoleh $t$ hitung sebesar 0, 435 dengan signifikansi 0, 666. Sedangkan $\mathrm{t}$ tabel dengan $\mathrm{df}=56$ diperoleh nilai sebesar 2, 003. Sehingga thitung < ttabel $(0,435<2,003)$ dan Nilai signifikansi lebih besar dari $0,05(0,666>0,05)$ maka kesimpulannya H0 diterima dan menolak H3. Jadi, X3 (NPF) berpengaruh negatif dan tidak signifikan terhadap profitabilitas (ROA) (Y) Bank Syariah Tahun 2009-2013.

d. Hasil secara simultan antara variabel bebas dalam hal ini Kecukupan Modal (CAR), Efisiensi Operasional (BOPO), dan Kualitas Pembiayaan (NPF) berpengaruh terhadap variabel terikat yakni tingkat Profitabilitas (ROA) Bank Syariah. Dengan ditunjukkan dari hasil perolehan Fhitung sebesar 20, 053 dengan nilai signifikansi sebesar 0, 000. Karena nilai signifikansi lebih kecil dari 0, $05(0,000<0,05)$ maka Ha diterima dan menolak Ho. 


\section{DAFTAR PUSTAKA}

Andri Soemitra, 2009, Bank dan Lembaga Keuangan Syariah, Kencana, Jakarta.

Edhi Satriyo Wibowo, Muhammad Syaichu, Analisis Pengaruh Suku Bunga, Inflasi, Car, Bopo, NPF Terhadap Profitabilitas Bank Syariah, Diponegoro Journal Of Management, Semarang, 2013, hlm., 4.

Heri Sudarsono, 2003, Bank dan Lembaga Keuangan Syariah, Edisi II, Ekonisia, Yogyakarta.

Kasmir, 2002, Manajemen Perbankan, PT. Raja Grafindo Persada, Jakarta.

Lia Dwi Musyarofatun, Analisis Faktor-Faktor yang Mempengaruhi Rentabilitas Bank Perkreditan Rakyat Di Kabupaten Magelang, Accounting Analysis Journal, Vol. I, No. 3, 2012, hlm., 60.

Mamduh M. Hanafi \& Abdul Halim, 2007, Laporan Keuangan, UPP STIM YKPN, Yogyakarta.

Muhammad Syafi'i Antonio, 2001, Bank Syari'ah Dari Teori Ke Praktek, Gema Insani Press, Jakarta.

Muhammad, 2005, Manajemen Bank Syariah, UPP AMP YKPN, Yogyakarta.

Muhammad, 2005, Manajemen Pembiayaan Bank Syariah, UPP AMP YKPN, Yogyakarta.

Muhammad, 2009, Dwi Suwiknyo, Akuntansi Perbankan Syariah, Trust Media, Yogyakarta.

Rachmadi Usman, 2009, Produk dan Akad Perbankan Syariah di Indonesia, PT. Citra Aditya Bakti, Bandung.

Ratih Agustina, Analisis Kualitas Pembiayaan dan Pengaruhnya Terhadap Efektivitas Pendapatan Pada PT. BPR Syariah PNM Al-Ma'soem Bandung, Jurnal UNIKOM, Bandung, 2009, hlm., 1.

Sofyan Syafri Harahap, 2002, Analisa Kritis Atas Laporan Keuangan, PT. Raja Grafindo Persada, Jakarta.

Taswan, 2010, Manajemen Perbankan (Konsep, Teknis, \& Aplikasi), Edisi II, UPP STIM YKPN, Yogyakarta.

Totok Budi Santoso, Sigit Triandaru, 2006, Bank dan Lembaga Keuangan Lain, Salemba Empat, Jakarta. 
Warkum Sumitro, 1996, Asas-Asas Perbankan Islam dan Lembaga-Lembaga Terkait (BMUI \& TAKAFUL) di Indonesia, PT. Raja Grafindo Persada, Jakarta.

Yuliani, Hubungan Efisiensi Operasional dengan Kinerja Profitabilitas pada Sektor Perbankan yang Go Publik Di Bursa Efek Jakarta, Jurnal Manajemen \& Bisnis Sriwijaya, Vol. V No. 10, 2007, hlm., 35.

Zubairi Hasan, 2009, Undang-Undang Perbankan Syari'ah : Titik Temu Hukum Islam dan Hukum Nasional, Edisi I, Rajawali Pers, Jakarta. 